Review

\title{
Fluoropyrimidine Modulation of the Anti-Tumor Immune Response-Prospects for Improved Colorectal Cancer Treatment
}

\author{
William H. Gmeiner (D) \\ Department of Cancer Biology, Wake Forest School of Medicine, Winston-Salem, NC 27157, USA; \\ bgmeiner@wakehealth.edu
}

Received: 25 May 2020; Accepted: 19 June 2020; Published: 21 June 2020

check for updates

\begin{abstract}
Chemotherapy modulates the anti-tumor immune response and outcomes depend on the balance of favorable and unfavorable effects of drugs on anti-tumor immunity. 5-Florouracil (5-FU) is widely used in adjuvant chemotherapy regimens to treat colorectal cancer (CRC) and provides a survival benefit. However, survival remains poor for CRC patients with advanced and metastatic disease and immune checkpoint blockade therapy benefits only a sub-set of CRC patients. Here we discuss the effects of 5-FU-based chemotherapy regimens to the anti-tumor immune response. We consider how different aspects of 5-FU's multi-factorial mechanism differentially affect malignant and immune cell populations. We summarize recent studies with polymeric fluoropyrimidines (e.g., F10, CF10) that enhance DNA-directed effects and discuss how such approaches may be used to enhance the anti-tumor immune response and improve outcomes.
\end{abstract}

Keywords: 5-Fluorouracil; thymidylate synthase; immunogenic cell death; immunotherapy; MDSCs; T-cells

\section{Introduction}

Immune surveillance is essential for limiting cancer incidence and an effective anti-tumor immune response is important for maintaining durable remissions in colorectal cancer (CRC) patients with locally advanced and metastatic disease. The most widely used drug for CRC treatment is 5-Fluorouracil (5-FU) [1-3]. Biochemical and immunomodulatory approaches to enhance 5-FU's efficacy have been implemented for decades [4]. For example, 5-FU+levamisole conferred a survival benefit for CRC patients with locally advanced disease (Duke's stage C) [5]. Levamisole is an immune modulating agent [6] that displayed synergy with 5-FU in CRC cells by increasing expression of class I human leukocyte antigens (HLA-1) [7]. Both type I and II interferons also were evaluated in combination with 5-FU and strong efficacy was found in some clinical studies consistent with their immunomodulatory properties [8]. Ultimately, immunomodulatory approaches to enhancing 5-FU efficacy were shown to be inferior to biochemical modulation with leucovorin (LV) [9], a reduced folate [10] that promotes thymidylate synthase (TS) inhibition by 5-FU [11]. TS is essential for de novo pyrimidine biosynthesis and its inhibition causes malignant cells to undergo "thymineless death" [12], a well-validated strategy for cancer treatment [3]. In recent years, there is increasing emphasis on enhancing the anti-tumor immune response thru use of immune-checkpoint blockade (ICB) [13]. While this strategy has impacted outcomes considerably in non-small cell lung cancer (NSCLC) [14], melanoma [15] and other malignancies [16], it has a lesser impact in CRC [17]. Understanding how 5-FU chemotherapy regimens affect the anti-tumor immune response in CRC is critical to devising new ways to harness the immune system to improve outcomes for CRC patients.

In this review, we discuss the survival benefit associated with adjuvant chemotherapy with 5-FU-based regimens for CRC [18] in the context of therapy-induced effects not only to malignant 
cells but also to the host anti-tumor response. We first summarize evidence for the survival benefit associated with 5-FU-based regimens and describe 5-FU's multi-factorial cytotoxic mechanism [19] that includes both DNA-directed [20,21] and RNA-mediated effects [22-24], as well as potential toxic effects resulting from degradation metabolites. We then summarize evidence that 5-FU modulates the anti-tumor immune response by reducing immunosuppressive cell populations (myeloid-derived suppressor cells (MDSCs), Tregs) and by stimulating immunogenic cell death (ICD,-i.e., damaging malignant cells to recruit their phagocytosis by dendritic cells (DCs) and ultimately generating an anti-tumor response mediated by effector T-cells. The favorable immunomodulatory properties of 5-FU are countered, however, by immunosuppressive and pro-inflammatory effects. Interestingly, both 5-FU-induced lymphodepletion [25] and gastrointestinal (GI)-tract inflammation [23,26] result from 5-FU's RNA-mediated effects. We summarize recent studies from our laboratory [27] that demonstrate that polymeric fluoropyrimidines (FPs; for example, F10, CF10 [28]) with primarily DNA-directed cytotoxic mechanism display improved anti-tumor activity and reduced GI-tract and hematopoietic toxicities relative to 5-FU. Thus, it may be possible to harness the anti-tumor immune response more effectively by altering the metabolite distribution of FPs to be more DNA-directed.

\section{Results}

Colorectal cancer (CRC) is a major cause of cancer-related mortality and causes 700,000 deaths annually worldwide [29] (51,000 in the U.S.). The mortality associated with colon cancer results almost exclusively from metastatic disease. Five-year survival rates for patients diagnosed at the regional and distant stages are $71 \%$ and $13 \%$, respectively [30]. Most patients with limited-stage disease undergo potentially curative surgical resection and adjuvant chemotherapy is administered to patients with stage III and high-risk stage II disease to eradicate micrometastatic disease. A survival benefit for adjuvant chemotherapy with 5-fluorouracil (5-FU)-based regimens in stage III CRC was first demonstrated in 1988 in the NSABP C-01 trial [31]. 5-FU-based regimens have been used since to reduce risk for disease recurrence and improve overall- and disease-free survival. 5-FU in combination with the reduced folate leucovorin (LV) has a demonstrated survival benefit in the adjuvant setting for stage II and III CRC [32], as well as a survival benefit for stage IV disease. 5-FU-based chemotherapy regimens such as FOLFOX (5-FU/LV/Oxaliplatin) [33] and FOLFIRI (5-FU/LV/Irinotecan) [34] display a further improved survival benefit in the metastatic setting relative to 5-FU/LV and these regimens are now in widespread use.

There is a growing appreciation that the survival benefit derived from 5-FU-based chemotherapy regimens is multi-factorial, resulting not only from direct cytotoxic effects to cancer cells but also by modulating the host anti-tumor immune response [35]. 5-FU modulates the host anti-tumor response by affecting multiple cell types. For example, 5-FU may cause some tumor cells to be more visible to the adaptive immune system, resulting in enhanced eradication of tumor cells by effector T-cells [36]. Further, 5-FU may be cytotoxic to immunosuppressive MDSCs [37], restoring anti-tumor immunity. However, any favorable impact of 5-FU to anti-tumor immunity may be countered by processes that attenuate any potential anti-tumor immune response. 5-FU causes GI-tract inflammation in most patients [38], resulting in chronic inflammation that may attenuate anti-tumor immunity. Further, 5-FU is myeloablative [39], with neutropenia and leukopenia occurring in many patients [25,40].

\subsection{Cytotoxic Mechanism of 5-FU}

Mechanistically, 5-FU is complex. 5-FU enters malignant cells by facilitated diffusion [41] and competes with Ura for metabolism by enzymes that mediate de novo pyrimidine biosynthesis [42]. 5-FU-derived metabolites affect both RNA- and DNA-mediated processes [42]. While most 5-FU-derived metabolites are processed with a similar efficiency to that of the native substrates, three types of metabolites display altered biochemical properties and are deleterious to specific cell types [19]-(i) DNA-directed (e.g., FdUMP, FdUTP); (ii) RNA-directed (FUTP); and (iii) degradation products (e.g., FBAL). Most 5-FU administered to humans $(\sim 85 \%)$ is degraded or excreted intact [43] and patients deficient in 5-FU 
catabolism due to genomic polymorphisms present in 5-10\% of the population are at risk for serious and potentially lethal 5-FU toxicities $[44,45]$ that may require therapeutic monitoring [46]. Among anabolic metabolites, ribonucleotides predominate over deoxyribonucleotides [47] and are associated with systemic toxicities that are reversed with Uridine [48], while DNA-directed effects are primarily responsible for the anti-tumor response [3].

\subsubsection{DNA-Directed Effects of 5-FU}

While 5-FU is inefficiently converted to deoxyribonucleotide metabolites $(<5 \%$ of administered dose) thru a multi-step process (Figure 1) [47], these metabolites are primarily responsible for 5-FU's direct cytotoxic effects to malignant cells [3]. FdUMP is a potent inhibitor of thymidylate synthase (TS), which catalyzes the reductive methylation of dUMP to thymidylate (TMP) [11]. TS is required for de novo pyrimidine biosynthesis required to support rapid proliferation of malignant cells. TS inhibition causes an imbalance in deoxynucleotide pools (i.e., elevated dATP/TTP ratio [49]) that contributes to replication stress [50]. Further, under the ensuing thymineless conditions, FdUTP becomes misincorporated into genomic DNA, which causes the trapping of DNA topoisomerase 1 cleavage complexes (Top1cc) [51,52]. Top1cc formation exacerbates replication stress and causes potentially lethal DNA double strand breaks due to collision with advancing replication forks [51]. We recently reviewed the entrapment of DNA topoisomerase-DNA complexes by nucleoside analogs and its role in cancer cell death [21]. Thymineless death induced by FPs involves activation of the extrinsic apoptotic pathway, which occurs via upregulation of Fas/FasL expression [53,54] or by altered sub-cellular localization of Fas death receptor without increased Fas expression [55] and sensitizes malignant cells to agonistic anti-Fas antibodies [55], consistent with sensitization to T-cell-mediated killing [56].

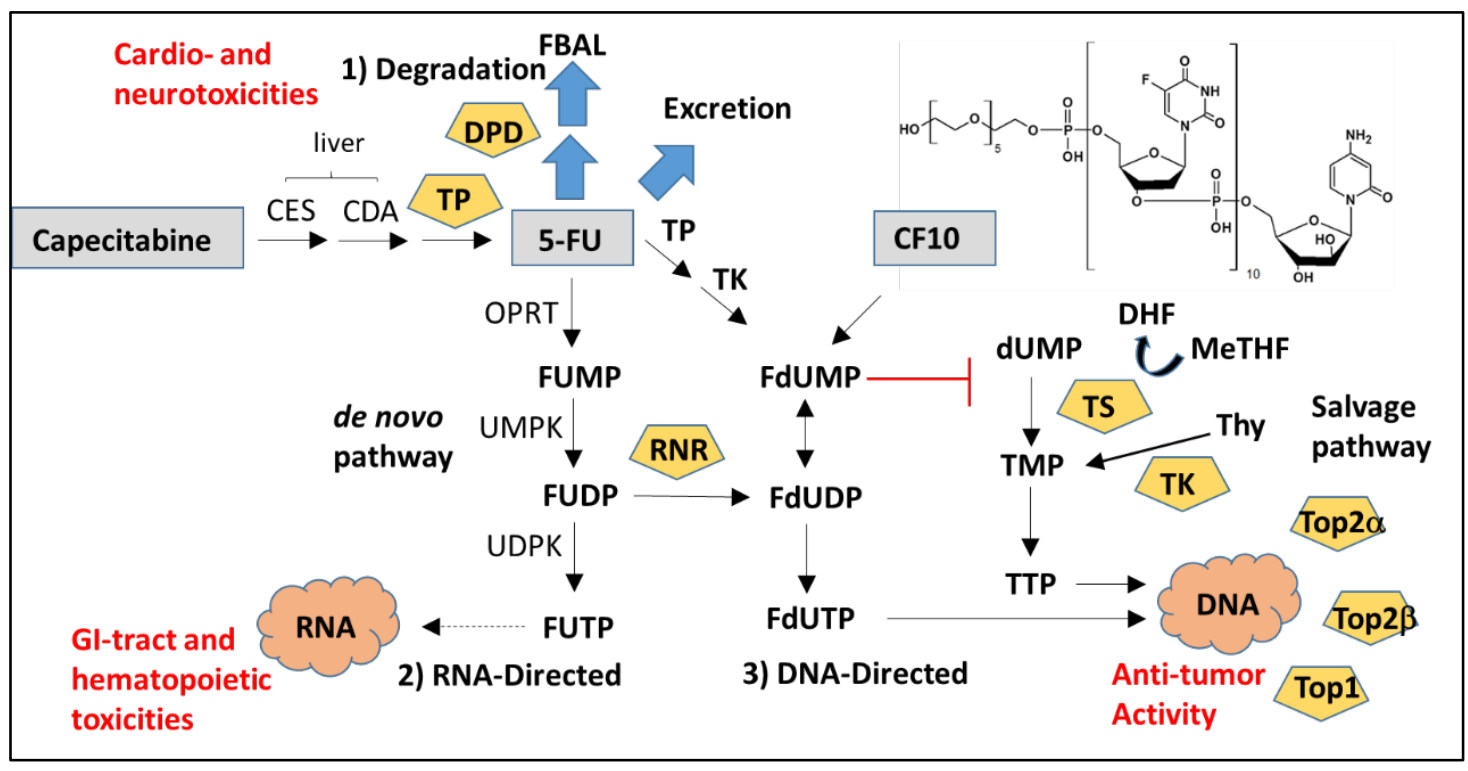

Figure 1. Overview of fluoropyrimidine metabolism. Fluoropyrimidines exert biological effects thru three types of metabolites: (1) Degradation; (2) RNA-directed; and (3) DNA-directed. Most 5-FU is either degraded or excreted intact and degradation metabolites contribute to cardio- and neurotoxicities. RNA-directed metabolites cause GI-tract and hematopoietic toxicities and contribute to immunosuppression. DNA-directed metabolites are responsible for the anti-cancer activity of fluoropyrimidines. Fluoropyrimidine polymers (e.g., CF10) are more efficiently converted to DNA-directed metabolites and may reduce the immunosuppressive and pro-inflammatory effects of 5-FU. 


\subsubsection{RNA-Directed Effects of 5-FU}

While rapidly proliferating malignant cells undergo thymineless death in response to 5-FU treatment [3], non-malignant cells, both differentiated and proliferative, undergo primarily apoptotic cell death due to altered RNA processing induced by 5-FU [23]. We and others, have shown that 5-FU incorporation into RNA perturbs RNA structure [57-59] and stability [60] contributing to its altered function [24]. 5-FU causes GI-tract toxicities that may be serious and are occasionally lethal, particularly in cancer patients deficient in 5-FU catabolism due to polymorphisms in DPYD [43]. 5-FU-induced GI-tract toxicities are reversed by Uridine (Urd) [48], consistent with an RNA-mediated process. 5-FU also causes myelosuppression [40], which may increase risk for infection [61]. 5-FU induced leukopenia may be reversed by Urd [25], consistent with an RNA-mediated origin. The effects of 5-FU on hematopoiesis [39] and on mature hematopoietic cells are important for understanding 5-FU's overall modulation of the immune anti-tumor response.

\subsubsection{Effects of 5-FU Degradation Metabolites}

While patients deficient in 5-FU catabolism are at increased risk for 5-FU toxicity mainly from elevated levels of ribonucleotide metabolites, the products of 5-FU catabolism, ( $\alpha$-fluoro- $\beta$-alanine (FBAL) [62] and fluoroacetate [63]), cause cardio [64]- and neurotoxicities [65] and are associated with hyperammonemia [66] that may be lethal. FBAL is an amino acid analog and its toxic effects may result from misincorporation into proteins while fluoroacetate could disrupt the tricarboxylic acid cycle [66]. 5-FU's degradation products have not been reported to affect immune cell function or the anti-tumor immune response; however, T-cell metabolism is important for anti-tumor immunity [67] and non-native metabolites including FBAL and fluoroacetate could exert a disruptive effect.

\section{5-FU Modulates the Anti-Tumor Immune Response}

Most, if not all, chemotherapy drugs affect the anti-tumor immune response to some extent [68]. The extent of modulation likely depends on the drug, the tumor-type and stage and the genomic characteristics of individual tumors, among a multitude of factors. The potential for chemotherapy to favorably impact the anti-tumor immune response may be considered in terms of two categories [69]-(i) Attenuating Immunosuppressive Cell Populations; and (ii) Stimulating Immunogenic Cell Death (ICD). In the first category, chemotherapy selectively eradicates cell populations that suppress the anti-tumor immune response (e.g., Treg, MDSC). In the second category, chemotherapy induces tumor cell death in a manner that renders dying tumor cells more visible to the immune system. These categories are not exclusive and an anti-cancer drug may modulate anti-tumor immunity thru processes in both categories as summarized for 5-FU in Sections 3.1 and 3.2, respectively. However, 5-FU also activates processes that are disruptive to the anti-tumor immune response that counter potentially favorable effects to anti-tumor immunity. 5-FU damages cells in the GI-tract [23] and this damage initiates an inflammatory response that is mediated thru IL-4 [26], a cytokine upregulated in many colon cancer patients that may adversely affect the anti-tumor immune response [70]. Further, 5-FU alters the composition of the gut microbiome, which also affects the anti-tumor immune response [71].

\subsection{5-FU Effects to MDSCs and $T_{\text {Regs }}$}

Myeloid-derived suppressor cells (MDSCs) are heterogeneous immature myeloid cells that fail to terminally differentiate and suppress the anti-tumor activities of $\mathrm{T}$ and NK cells [72]. In response to acute inflammation, MDSCs expand and differentiate into monocytes and neutrophils in a process knowns as myelopoiesis [73]. In cancer, MDSCs expand and become activated but they do not fully differentiate into monocytes and neutrophils. MDSCs accumulate in tumor and peripheral lymphoid organs in tumor-bearing hosts and impact effector cell function thru multiple mechanisms that include [74]-(i) inhibiting CD4+ and CD8+ T-cell proliferation and activation; (ii) altering 
macrophage to a type 2 phenotype; (iii) inhibiting the cytotoxicity of NK cells; and (iv) inducing Treg cells to escalate immunosuppression.

Tregs are a sub-population of CD4+ T-cells that display immunosuppressive function. Specifically, TRegs suppress conventional $\mathrm{T}$ helper (Th) cells and contribute to maintenance of immunologic self-tolerance [75]. TRegs infiltrate into the tumor microenvironment attracted by chemokine gradients (e.g., CCR4-CCL17/22) and, upon activation, inhibit antitumor immune responses. Effector/activated Treg cells (eTreg) inhibit maturation of antigen-specific DCs and also exert non-specific immunosuppressive effects through IL-2 consumption and degradation of ATP to adenosine which impairs T-cell function [76,77] (Figure 2)., Further, Tregs secrete immunosuppressive cytokines IL-10, TGF- $\beta$ and Il-35 [78] and undergo proliferation in response to tumor-derived factors including TGF- $\beta$ and IL-10 [79]. eTReg also express immune checkpoint molecules (e.g., CTLA-4) to inhibit cytotoxic T-cells and suppress the anti-tumor immune response [80].

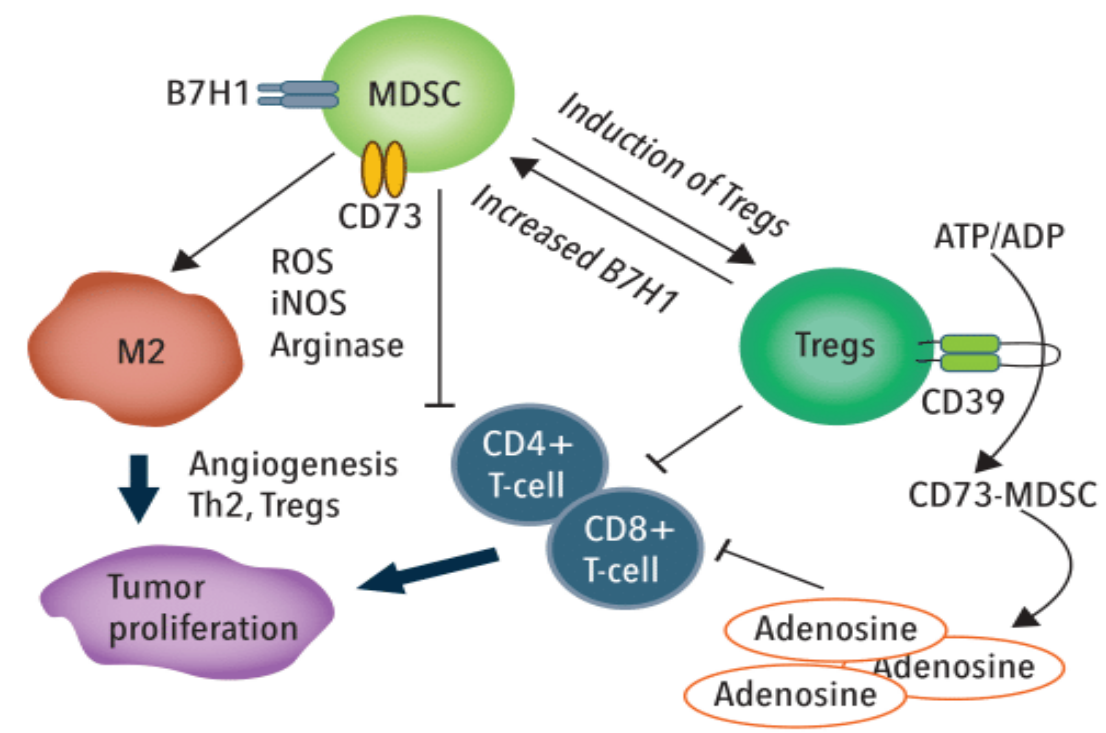

Figure 2. Myeloid-derived suppressor cells (MDSCs) and $\mathrm{T}_{\text {regs }}$ suppress the anti-tumor activity of T-cells thru multiple mechanisms.

Clinical studies show increased MDSC (CD33+CD11b+HLA-DR-) are present in tumor tissue relative to para-neoplastic tissue [81]. Further, the MDSC percentage in PBMC from CRC patients was significantly greater than from healthy donors and both MDSC and Treg (CD4+CD25highFOXP3+) populations in PBMCs significantly decreased following tumor resection. CRC cells promote MDSC expansion, which suppresses $\mathrm{T}$ cell proliferation resulting in enhanced CRC cell growth. The clinical significance of MDSC levels for CRC outcomes was demonstrated by studies showing elevated CD33+ MDSC cells in CRC patients were associated with significantly reduced disease-free and overall survival [82]. Mechanistic studies revealed tumor YAP1 expression promoted MDSC induction by stimulating granulocyte-macrophage colony-stimulating factor (GM-CSF) secretion thru increased COX-2, pAkt and P-p65. While Tregs are increased in CRC, effects are complex and Tregs may have protective or suppressive function depending on disease stage among other factors $[83,84]$.

Among the chemotherapeutic drugs shown to selectively deplete MDSCs in pre-clinical studies are Gemcitabine (Gem) [85] and 5-FU [37]. In a 4T1/Balb-c breast cancer syngeneic model Gem but not cyclophosphamide, significantly decreased both \%-MDSC in the spleen and absolute MDSC number. While MDSC depletion rescued T-cell function, it did not enhance anti-tumor activity. 5-FU treatment in a syngeneic thyoma model was superior to Gem in MDSC depletion through increased induction of MDSC apoptosis. 5-FU induced MDSC depletion, promoted IFN $\gamma$ production by tumor-infiltrating CD8+ T-cells and stimulated a T-cell-dependent antitumor effect. While 5-FU induced MDSC depletion in some tumor models, 5-FU's effects on MDSCs is dependent both on the tumor model and the 
dosing regimen [74]. MDSC numbers were not significantly decreased 7 days post-treatment in studies in which 5-FU was dosed repeatedly, indicating MDSC number may stabilize with repeated treatment. Further, 5-FU activates the inflammasome in dying MDSCs leading to IL- $1 \beta$ secretion and IL-17 production by Th17 cells that increased angiogenesis and stimulated tumor growth. 5-FU also modulates levels of TRegs in a dose- and time-dependent manner [86].

Clinical studies demonstrated that 5-FU-based regimens modulate levels of immunosuppressive cells and that a favorable response is associated with chemotherapy-induced reduction in immunosuppressive cell populations [87,88]. Elevated levels of granulocytic MDSCs (gMDSCs) were associated with poor prognosis in a longitudinal study of mCRC patients treated with FOLFOX-bevacizumab. Patients in which FOLFOX-bevacizumab treatment decreased gMDSC levels displayed a better survival outcome than those that did not, although these studies do not distinguish direct cytotoxic effects to immunosuppressive cell populations from indirect effects. FOLFOX-bevacizumab therapy was also associated with decreased Treg and increased Th17 cell frequency [87]. However, 5-FU-based regimens are not uniformly effective at reducing immunosuppressive cell populations as FOLFIRI displayed an opposite effect from FOLFOX on MDSC populations [88]. Effects of 5-FU to TReg levels and influence on outcomes is not as defined as for MDSCs although the CD8:Treg ratio is associated with favorable outcomes in $\mathrm{mCRC}$ patients treated with anti-VEGF therapy.

MDSCs and Tregs are important mediators of immunosuppression affected by chemotherapy [89] but other cell populations that contribute to immunosuppression may be responsive to 5-FU chemotherapy. Upregulation of cytotoxic T-cell cell populations specific for tumor antigens is central to an anti-tumor immune response and elevated CD3+ and CD8+ tumor-infiltrating lymphocytes correlates with a favorable outcome in CRC [90,91]. Clinical studies indicate select leukocyte sub-populations detected in peripheral blood mononuclear cells (PBMCs) systematically differ between CRC patients and healthy controls. Consistent with CRC patients presenting with a general immunocompromised state, CRC patients and healthy donors displayed similar proportions of circulating T-cells (both CD4+ and CD8+), NK cells and NKT cells [92] but circulating T-regs were increased in CRC patients [79]. While the total NK population in PBMCs did not differ between CRC patients and healthy donors, CRC patients displayed reduced expression of natural cytotoxicity receptors (NCRs) NKp44 and NKp46 on CD56dim NK cells and NKT-like cells. NCRs mediate NK cell killing and IFN $\gamma$ release [93]. The effects of NK levels on CRC outcomes is controversial with one study reporting above-median percentage of CD16+ NKT-like cells was associated with decreased disease-free survival for CRC patients [92], while another study found the percentage of NK cells in blood was an independent predictor of survival in CRC patients [94]. CD16 activates resting NK cells thru engagement with antibodies; however, NK cells may become exhausted and show lower cytotoxic activity thru CD16 stimulation [95]. CD16+CD56+ NK cells post-chemotherapy with 5-FU-based regimens also negatively correlated with outcomes consistent with chemotherapy potentially modulating outcomes by affecting specific sub-sets of NK cells [96]. In this regard, we have shown that 5-FU decreases viability of an immortalized NK population ex vivo, while the DNA-directed fluoropyrimidine (FP) polymer CF10 does not (Gmeiner and Soto-Pantojo, in preparation). Reduction of CD16+ NK cells following 5-FU-based chemotherapy was also detected in clinical studies [97].

\subsection{5-FU Stimulation of Immunogenic Cell Death}

Malignant cells are induced by chemotherapy to undergo any one of several cell death processes (e.g., apoptosis, necrosis, etc.). The mode of cell death is an important determinant in activating immunogenic cell death (ICD), an immune response capable of contributing to further tumor eradication. In general, the extent to which chemotherapy-induced malignant cell death is immunogenic depends on both the antigenicity of target malignant cells (i.e., expression of cancer-specific epitopes) and adjuvanticity or propensity to enhance cross-presentation of cancer-specific antigens to CD8+ T-cells by dendritic cells via MHC-I. Antigenicity is determined, in part, by mutational burden, which depends 
on DNA mismatch repair among other factors. Microsatellite instable (MSI) CRC tumors, in general, having greater mutational burden than MSS disease. Recruitment of DCs to dying cancer cells is stimulated by the secretion of damage-associated molecular patterns (DAMPS) [98]. A necessary step in the recognition of dying malignant cells by phagocytes is Calreticulin (CRT) cell surface expression. CRT is an endoplasmic reticulum (ER) chaperone and its presentation in complex with ERp57 [99] on the surface of malignant cells provides a potent "eat me" signal for phagocytic engulfment via the HSP protein-CD91 pathway [100]. DCs and macrophages localize to dying cells via an ATP gradient ("find me" signal), created by autophagy-dependent ATP release from dying cells [101]. The licensing of DCs to process and present tumor antigens requires interaction of DAMPs (e.g., HMGB1, HSP70) released from dying tumor cells, with Toll-like receptor 4 (TLR4) on DCs [102]. The relevance of this process for the immunogenicity of cancer chemotherapy is demonstrated by a TLR4 polymorphism affecting HMGB1 binding predicting relapse in breast cancer patients treated with anthracycline chemotherapy [102]. DCs that phagocytose dying tumor cells increase presentation of tumor-associated antigens and elicit cytotoxic responses by autologous lymphocytes.

Chemotherapeutic drugs may be classified as ICD-inducers, in part, based on vaccination assays in which mice injected with drug-treated tumor cells are protected against subsequent re-challenge with the same tumor. Using this and related criteria several chemotherapy drugs have been categorized as ICD-inducers including anthracyclines, cyclophosphamide, mitoxantrone and bortezomib [103]. Recent studies indicate that by the same criteria, 5-FU and clinically relevant combinations are ICD-inducers [36]. 5-FU in combination with oxaliplatin and leucovorin comprises the FOLFOX regimen widely used for CRC treatment. Both 5-FU and OXA induced HMGB1 and HSP70 release from CRC cells and the 5-FU/OXA combination was more effective than either drug at inducing DAMP secretion. Further, HMGB1 and HSP70 were increased in serum from CRC patients following treatment with FOLFOX establishing potential clinical relevance [36]. Supernatants from 5-FU and 5-FU/OXA-treated human CRC cells induced maturation of human DCs based on upregulated HLA-DR, CD80 and CD86 and DC maturation was inhibited by antibodies to TLR4. Analogous effects were detected with mouse CRC cells and mouse DCs. Finally, DCs pulsed with supernatants from 5-FU and 5-FU/OXA-treated mouse cancer cells displayed an enhanced anti-tumor effect relative to immunization with DCs that were pulsed with supernatants from untreated cells. While these studies are supportive of a role for ICD in contributing to the anti-tumor effects and survival benefit of 5-FU-based chemotherapy regimens in CRC, these studies used a single syngeneic model (CT26/Balb-c) that may not be reflective of human CRC. In particular, CT-26 expresses wild-type p53 [104], while approximately half of CRC tumors express mutant p53 [105]. This is significant because the response of CRC cells and induction of apoptosis following 5-FU-treatment depends on p53 expression [106]. Further, the efficacy of adjuvant 5-FU in stage III colon cancer patients is limited to patients expressing wt-p53 [107]. In this regard, we are developing polymeric FPs that differ from 5-FU and other anti-cancer drugs and these induce apoptosis regardless of p53 expression [108]. Further studies are needed to establish the generality and limitations of 5-FU-induced ICD in murine model systems and to develop FPs that are more potent and more general inducers of ICD in CRC patients.

\subsection{5-FU Effects on Immune Cells Are Dynamic}

5-FU chemotherapy is immunosuppressive and a linear relationship between 5-FU plasma concentration and decreased leukocyte count was observed [109]. A recent study indicated 70\% of CRC patients treated with 5-FU according to the Mayo schedule experienced $\geq$ grade 1 hematological toxicities (neutropenia and/or leukopenia) [40]. Further, 5-FU toxicity increases healthcare costs with toxicity-related hospitalizations occurring at a higher rate in 5-FU treated patients relative to those not receiving chemotherapy ( $31 \%$ vs. $8 \%$ ) with increased cost of $\$ 2716$ per patient [110]. While 5-FU causes immunosuppression in many patients, studies in mice reveal the effects of 5-FU on hematopoietic populations are dynamic. Thus, 5-FU's initial myeloablative effects stimulate a rebound response that tends to restore steady-state levels [39], which is consistent with 5-FU's net impact on anti-tumor 
immunity reflecting a balance between opposing forces. 5-FU treatment resulted in a rebound in HSCs following initial reduction. HSC increase was Tpo-regulated and 5-FU but not irradiation, induced overexpression of Tie-2/Angpt-1 by stromal cells of the bone marrow [39]. 5-FU eliminates committed progenitors in bone marrow but also effects long-term reconstituting stem cells by decreasing expression of c-kit [111]. While a rebound effect in HSCs following single, high dose 5-FU treatment was observed in mice [39], the effects of multiple treatments simulating clinical regimens are more complex. Studies using the CT26/Balb-c model demonstrated that multiple cycles of 5-FU treatment improved tumor growth inhibition better than a single cycle but more extensive dosing did not improve survival [112]. Immune cell sub-populations from PBMCs did not differ between treated and control groups except a significant reduction in B-cells with multiple treatments. Multiple cycles of 5-FU, however, decreased proliferation of CD8+ T-cells specific for CT26, indicating the potential for 5-FU to attenuate anti-tumor immunity in some instances by inhibiting proliferation of tumor-specific T-cell populations [112].

\section{Modulation of 5-FU-Induced Anti-Tumor Immunity}

\subsection{Direct and Indirect Modulation of 5-FU by IFNs}

Multiple studies have investigated the potential of interferons (IFNs) to enhance the anti-tumor activity of 5-FU in colorectal cancer patients. Several clinical studies evaluated 5-FU in combination with the type I interferon IFN $\alpha$. Clinical studies were initiated in response to pre-clinical studies that demonstrated synergy for the IFN $\alpha / 5$-FU combination towards CRC cells [8,113]. Synergy was associated with increased thymidine phosphorylase expression [114], increased FdUMP levels, enhanced TS inhibition and greater DNA damage [115]. IFN- $\alpha 2 b$ was also found to modulate 5-FU pharmacokinetics [116], decreasing clearance, in part, by decreasing activity of dihydropyrimidine dehydrogenase [117]. IFN $\alpha$ could potentiate 5-FU activity for CRC treatment by enhancing activities of effector cell or modulating display of HLA class I antigens [118]. Meta-analysis of data from multiple trials concluded however that IFN $\alpha$ did not increase the efficacy of 5-FU or 5-FU+LV and that 5-FU+IFN $\alpha$ was significantly inferior to 5-FU+LV [9]. The type II IFN IFN $\gamma$ was also evaluated for enhancing 5-FU's anti-tumor activity. IFN $\gamma$ is associated with anti-proliferative and anti-tumor mechanisms but also may have pro-tumor activities (downregulating MHC, upregulating PDL1) and clinical studies have had limited success [119]. Both 5-FU and IFN $\gamma$ increased expression of carcinoembryonic antigen (CEA) by CRC cells although the combination was not synergistic. 5-FU and IFN $\gamma$ both increased MHC I by CRC cells but neither induced expression of the co-stimulatory molecule B7-1 [120]. IFN $\gamma$ did not enhance 5-FU-mediated DNA damage [115]. IFN $\gamma$ did not display single agent activity in colon cancer [121], although promising results were obtained for the 5-FU/IFN $\gamma$ combination for treatment of advanced hepatocellular carcinoma [122].

Indirect activation of interferon genes may also contribute to anti-tumor immunity thru activation of the STING (stimulator of interferon genes) pathway. STING activates interferon regulatory factor 3 (IRF3) and NF- KB stimulating production of cytokines and type I interferons. STING is activated in response to sensing of foreign DNA (i.e., viral, bacterial) by cyclic GMP-AMP synthase (cGAS). While the STING pathway primarily functions to sense foreign DNA and stimulate an immune response, STING also is activated in response to genomic DNA in the cytosol that could result from aberrant cell division or treatment-induced DNA damage. Radiation increases tumor production of IFN $\beta$ and antitumor efficacy of radiation depends on IFN signaling [123]. Further, IFN $\beta$ production in response to radiation of tumor cells is STING-dependent [124]. Thus, treatments that induce DNA damage, including fluoropyrimidine drugs, could potentially result in cytosolic DNA and STING pathway activation and contribute to anti-tumor immunity, in part, thru stimulating production of type I interferons. In this regard, Mus81-mediated DNA damage promoted cytosolic DNA accumulation in malignant cells contributing to STING activation and an enhanced anti-tumor immune response [125]. Mus81 is activated in response to replication stress induced by anti-cancer drugs [126]. Our studies with polymeric fluoropyrimidines demonstrate these compounds are more efficient inducers of replication 
stress relative to 5-FU [50], consistent with STING pathway activation being relatively more important for polymeric FPs than for 5-FU. Recent studies indicate the potential for STING pathway activation to potentiate 5-FU treatment. Exogenous administration of cGAMP, the cyclic nucleotide product resulting from cGAS activation, exerts single-agent anti-tumor activity [127]. Further, cGAMP enhanced the activity of 5-FU and reduced its toxicity. Hence, indirect production of IFN $\beta$ thru exogenous activation of the STING pathway may enhance 5-FU efficacy, although this approach has not yet been evaluated in clinical trials.

The mechanism by which STING activation enhances antitumor immunity involves DC activation and priming antitumor responses thru effector CD8+ T-cells. STING is predominantly expressed in DCs, macrophages, T-cells and epithelial cells [128]. STING-deficient DCs display an impaired ability to cross-prime CD8+ T cells following tumor cell irradiation [124]. Thus, engulfed tumor cells with damaged DNA may activate STING in DCs resulting in IFN $\beta$ production functioning in a paracrine or autocrine manner to enhance tumor antigen cross-presentation to T-cells $[129,130]$. The positive anti-tumor immune effects mediated by the STING pathway are countered, however, by pro-tumorigenic effects in certain contexts. STING activation can result in chronic inflammation contributing to tumor progression, in part by inducing indoleamine 2,3 dioxygenase (IDO) expression [131], which activates Tregs and suppresses effector and helper T-cells. Further, STING deficiency decreased MDSC and promoted tumor CD8+ tumor infiltration in the Lewis lung carcinoma model, consistent with an immunosuppressive function [132]. The potential enhancement of 5-FU and other anti-cancer drugs by STING activation still requires clinical validation.

\subsection{Combining 5-FU-Based Chemotherapy with Immune Checkpoint Blockade}

An anti-tumor immune response including recognition of malignant cells by effector T-cells is essential for a durable response to any cancer treatment. Even in cases where activated T-cells that recognize tumor-specific antigens are present, the anti-tumor effect may be muted by upregulation of immune checkpoint molecules on the surface of malignant cells, effector T-cells and other cell populations. For some malignancies, including NSCLC and melanoma, the upregulation of PD-L1 by tumor cells and PD-1 and CTLA-4 by effector T-cells leads to inhibitory interactions that attenuate tumor-directed T-cell cytotoxicity and antibodies directed at inhibiting these checkpoint interactions have had a profound impact on outcomes. Immune checkpoint inhibitors (ICIs), such as Nivolumab and Pembrolizumab, directed against PD-1, Atezolizumab and Durvalumab directed against PD-L1 and Ipilimumab targeting CTLA-4 and PD-1 display strong efficacy in NSCLC [133]. The activity of checkpoint inhibitors in CRC, however, is presently limited to a sub-set of CRC patients with high microsatellite instability (MSI-H) being the predominant stratifying factor. MSI-H CRC displays increased mutational burden relative to MSS disease and is associated with more favorable outcomes [134], consistent with increased anti-tumor immune response [135]. However, efficient tumor eradication by the immune system is countered by elevated PD-L1 expression by MSI-H CRC cells and elevated PD-1 and CTLA-4 by effector T-cells [136]. Clinical studies with Nivolumab and Pembrolizumab display promising activity for MSI CRC and other patients with high mutational burden and their use is recommended for patients with chemoresistant, MMR-deficient metastatic CRC [137].

Pre-clinical studies evaluating chemotherapy in combination with ICIs have shown that while favorable interactions can occur, effects depend on the tumor model, the type of chemotherapy and the ICI. Chemotherapy, including 5-FU [138], upregulated PD-L1 expression on CRC cells with the effects greatest for camptothecin [139]. The combination of capecitabine+oxaliplatin chemotherapy enhanced anti-PD1 ICI in an MC-38 CRC model [140]. While neither 5-FU nor OXA significantly enhanced anti-PD1 therapy in a CT-26/Balb-c model, FOLFOX/anti-PD1 therapy was highly effective resulting in long-term survival [141]. FOLFOX was shown to upregulate PD-L1 expression on tumor cells and to induce tumor infiltration by PD1+ CD8 T cells and this induction of adaptive immune resistance was countered by anti-PD1 therapy. FOLFOX induced PD-L1 tumor cell expression and stimulated CD8+ T 
cell infiltration in CRC patients indicating anti-PD1 therapy may be used effectively in combination with FOLFOX for CRC treatment [141]. The potential for ICI to enhance the efficacy of 5-FU-based chemotherapy is currently undergoing clinical investigation [142]. A Phase II study of FOLFOX and anti-PD-1 (Pembrolizumab) achieved an overall objective response rate of 53\%, which was particularly encouraging in that the patient population was predominantly MSS CRC [143]. The combination was safe and tolerable with no grade 4-5 treatment related adverse effects [144]. While 5-FU in the context of FOLFOX appears promising for enhancing anti-PD1/PD-L1 ICI therapy and extending ICI to MSS disease, the mechanistic basis is not known. In particular, 5-FU the relative contribution of TS inhibition and DNA-directed effects relative to RNA-mediated effects requires further elucidation

\section{Novel Chemical Approaches to Modulating 5-FU's Anti-Tumor Response}

TS inhibition [11] is central to the anti-tumor activities of 5-FU [3] and may be important for stimulating the anti-tumor immune response and enhancing activity of ICI therapy. However, a major limitation of 5-FU is its inefficient conversion to FdUMP [47]. In principle, the deoxynucleotide FdU would generate reduced ribonucleotide metabolites relative to 5-FU; however, FdU is rapidly taken up by the liver and metabolized to 5-FU and its clinical use is limited to hepatic arterial infusion for treatment of liver metastasis [145,146]. 5-FU is now always co-administered with LV to enhance TS inhibition under low folate conditions; however, this does not reduce toxicities nor does it improve overall survival [19]. To overcome this limitation we have developed polymeric FPs (e.g., F10, CF10) that are more directly converted to FdUMP [27] and display greater TS inhibitory activity, cause greater DNA damage and exert improved anti-tumor activity relative to 5-FU in multiple pre-clinical models [108,147-149].

We recently demonstrated the 2nd generation polymeric FP CF10 displayed significantly improved anti-tumor activity relative to 5-FU in an orthotopic colon cancer model consistent with the potential of polymeric FPs to provide a survival benefit for CRC patients. The realization of a clinical benefit for CF10 depends on multiple factors among which effects on anti-tumor immunity are of high importance. CF10 is expected to differ from 5-FU on its effects to anti-tumor immunity because mechanistically it is more DNA-directed while 5-FU exerts both RNA- and DNA-directed effects. The extent of the mechanistic difference between F10 and 5-FU was demonstrated by COMPARE analysis of data from the NCI60 cell line screen, which showed low correlation between these drugs consistent with dissimilar mechanisms [52]. Further, we showed 5-FU-induced apoptosis in CRC cells was p53-dependent and rescued by Uridine while F10's effects were p53-indepedendent and not reversed by Uridine [150]. Apart from distinguishing polymeric FPs from 5-FU mechanistically, these findings have potential implications for anti-tumor immunity since mode of cell death affects DAMP secretion, DC cell maturation and ultimately the recognition of malignant cells as foreign by effector T-cells. Additional studies are needed to determine if polymeric FPs differ from 5-FU in these important endpoints. CF10 and F10 display improved anti-tumor activity relative to 5-FU in both syngeneic tumor models [108,149] and xenograft studies in immunodeficient mice consistent with polymeric FPs not inducing decreased levels of immunogenic cell death relative to 5-FU.

The RNA-mediated effects of 5-FU cause GI-tract [23] and hematopoietic toxicities [25], both of which attenuate the anti-tumor response. Consistent with its mechanism being primarily DNA-directed, we have demonstrated that CF10 induces less GI-tract damage and less hematopoietic toxicity than 5-FU. 5-FU-induced GI-tract inflammation is IL-4-dependent [26] and IL-4 is upregulated in CRC and contributes to an immunosuppressive environment [70]. Since CF10 causes reduced GI-tract damage and less inflammation than 5-FU, it may exert reduced immunosuppressive effects contributing to an improved overall anti-tumor response. GI-tract damage and inflammation result from RNA-mediated processes perturbed by 5-FU that have not been elucidated in molecular detail. While both GI-tract and hematopoietic tissues include proliferative cells that are potentially vulnerable to CF10's DNA-directed activities, proliferation in non-malignant tissue may use the salvage pathway for Thy needed for DNA replication, while malignant cells may be more reliant on de novo Thy biosynthesis. This difference 
on reliance on de novo Thy biosynthesis may provide the basis for the relatively larger therapeutic window we observe for CF10 relative to 5-FU in murine anti-tumor studies. Ultimately, clinical studies are needed to determine if the therapeutic advantages for CF10 relative to 5-FU also occur in humans and if CF10 initiates a more favorable anti-tumor immune response and improves outcomes.

\section{Conclusions}

5-FU and 5-FU-based regimens display a survival benefit in stage II, III and IV CRC. The effects of 5-FU to the anti-tumor immune response are an important consideration both in understanding efficacy achieved with 5-FU and in developing improved FP drugs and novel combinations that might improve survival, which remains dismal for CRC patients with late-stage disease. 5-FU exerts biological effects thru DNA-, RNA- and degradation metabolites [19]. The anti-tumor activity of 5-FU results primarily from TS inhibition and DNA-directed metabolites but 5-FU is inefficiently converted to deoxynucleotide metabolites [47]. The RNA-directed activities of 5-FU cause GI-tract [23] and hematopoietic [25] toxicities that may be serious, particularly in patients deficient in 5-FU catabolism [43]. While in most instances these toxicities are manageable, they are occasionally lethal. Further, lymphodepletion and GI-tract inflammation may contribute to 5-FU-induced immunosuppression that limits the anti-tumor immune response contributing to sub-optimal outcomes. While some studies reported that 5-FU decreased immunosuppressive MDSC and Treg cell populations consistent with enhancing anti-tumor immunity, 5-FU also was shown to activate the inflammasome in dying MDSCs leading to IL-1 $\beta$ secretion that increased angiogenesis and stimulated tumor growth. 5-FU also induced DAMP secretion from dying CRC cells that activated DCs, which could then be used to stimulate a T-cell-mediated response to the same tumor type in other mice. The immunogenic effects of 5-FU may be limited to malignancies with a restricted genomic profile, such as wtp53, that is required for it to efficiently activate apoptosis. The polymeric FP CF10 induced primarily DNA-directed cell death processes and greater anti-tumor activity than 5-FU in multiple pre-clinical models. CF10 may be effective at inducing immunogenic cell death in malignancies in which 5-FU is ineffective. CF10 and F10 also caused less GI-tract inflammation and less hematopoietic toxicity than 5-FU [108], consistent with reduced immunosuppression. The effects of CF10 on modulating immunogenic cell death warrant further investigation.

Funding: Research reported in this publication was funded by a Pilot Grant from the Cancer Genomics Program of the Wake Forest Baptist Comprehensive Cancer Center, which is supported by the National Cancer Institute's Cancer Center Support Grant (P30CA012197). Gmeiner WH is supported by NIH grant (NIH-NCI R21 CA218933).

Acknowledgments: The author is grateful to Pierre Triozzi for proof reading of the manuscript and Creative Communications for help with figure presentation.

Conflicts of Interest: W.G. is an inventor on a pending patent application on CF10 for treatment of colorectal cancer.

\section{References}

1. Heidelberger, C.; Chaudhuri, N.K.; Danneberg, P.; Mooren, D.; Griesbach, L.; Duschinsky, R.; Schnitzer, R.J.; Pleven, E.; Scheiner, J. Fluorinated pyrimidines, a new class of tumour-inhibitory compounds. Nature 1957, 179, 663-666. [CrossRef] [PubMed]

2. Punt, C.J.; Koopman, M.; Vermeulen, L. From tumour heterogeneity to advances in precision treatment of colorectal cancer. Nat. Rev. Clin. Oncol. 2016. [CrossRef] [PubMed]

3. Wilson, P.M.; Danenberg, P.V.; Johnston, P.G.; Lenz, H.J.; Ladner, R.D. Standing the test of time: Targeting thymidylate biosynthesis in cancer therapy. Nat. Rev. Clin. Oncol. 2014, 11, 282-298. [CrossRef] [PubMed]

4. Grem, J.L. Mechanisms of Action and Modulation of Fluorouracil. Semin. Radiat. Oncol. 1997, 7, $249-259$. [CrossRef]

5. Skillings, J.R.; Levine, M.; Rayner, H.L.; Eisenhauer, E.; Erlichman, C.; Germond, C.; Kerr, I.; Lofters, W.; Maroun, J.; Yoshida, S. Levamisole and 5-fluorouracil therapy for resected colon cancer: A new indication. CMAJ 1991, 144, 297-301.

6. Renoux, G. The general immunopharmacology of levamisole. Drugs 1980, 20, 89-99. [CrossRef] 
7. AbdAlla, E.E.; Blair, G.E.; Jones, R.A.; Sue-Ling, H.M.; Johnston, D. Mechanism of synergy of levamisole and fluorouracil: Induction of human leukocyte antigen class I in a colorectal cancer cell line. J. Natl Cancer Inst. 1995, 87, 489-496. [CrossRef]

8. Wadler, S.; Schwartz, E.L. Antineoplastic activity of the combination of interferon and cytotoxic agents against experimental and human malignancies: A review. Cancer Res. 1990, 50, 3473-3486.

9. Thirion, P.; Piedbois, P.; Buyse, M.; O’Dwyer, P.J.; Cunningham, D.; Man, A.; Greco, F.A.; Colucci, G.; Kohne, C.H.; Di Constanzo, F.; et al. Alpha-interferon does not increase the efficacy of 5-fluorouracil in advanced colorectal cancer. Br. J. Cancer 2001, 84, 611-620. [CrossRef]

10. Rustum, Y.M. Clinical implications of 5-FU modulation. Oncology (Williston Park) 1999, 13, $22-25$.

11. Gmeiner, W.H. Novel chemical strategies for thymidylate synthase inhibition. Curr. Med. Chem. 2005, 12, 191-202. [CrossRef] [PubMed]

12. Hanawalt, P.C. A balanced perspective on unbalanced growth and thymineless death. Front. Microbiol. 2015, 6, 504. [CrossRef] [PubMed]

13. Postow, M.A.; Callahan, M.K.; Wolchok, J.D. Immune Checkpoint Blockade in Cancer Therapy. J. Clin. Oncol. 2015, 33, 1974-1982. [CrossRef] [PubMed]

14. Yan, Y.F.; Zheng, Y.F.; Ming, P.P.; Deng, X.X.; Ge, W.; Wu, Y.G. Immune checkpoint inhibitors in non-small-cell lung cancer: Current status and future directions. Brief. Funct Genom. 2019, 18, 147-156. [CrossRef] [PubMed]

15. Queirolo, P.; Boutros, A.; Tanda, E.; Spagnolo, F.; Quaglino, P. Immune-checkpoint inhibitors for the treatment of metastatic melanoma: A model of cancer immunotherapy. Semin. Cancer Biol. 2019, 59, 290-297. [CrossRef] [PubMed]

16. Wang, X.; Guo, G.; Guan, H.; Yu, Y.; Lu, J.; Yu, J. Challenges and potential of PD-1/PD-L1 checkpoint blockade immunotherapy for glioblastoma. J. Exp. Clin. Cancer Res. 2019, 38, 87. [CrossRef]

17. Hermel, D.J.; Sigal, D. The Emerging Role of Checkpoint Inhibition in Microsatellite Stable Colorectal Cancer. J. Pers. Med. 2019, 9, 5. [CrossRef]

18. Carrato, A. Adjuvant treatment of colorectal cancer. Gastrointest. Cancer Res. 2008, 2 (Suppl. S4), S42-S46.

19. Longley, D.B.; Harkin, D.P.; Johnston, P.G. 5-fluorouracil: Mechanisms of action and clinical strategies. Nat. Rev. Cancer 2003, 3, 330-338. [CrossRef]

20. Lawrence, T.S.; Davis, M.A.; Maybaum, J. Dependence of 5-fluorouracil-mediated radiosensitization on DNA-directed effects. Int. J. Radiat. Oncol. Biol. Phys. 1994, 29, 519-523. [CrossRef]

21. Gmeiner, W.H. Entrapment of DNA topoisomerase-DNA complexes by nucleotide/nucleoside analogs. Cancer Drug Resist. 2019, 2, 994-1001. [CrossRef] [PubMed]

22. Mojardin, L.; Botet, J.; Quintales, L.; Moreno, S.; Salas, M. New insights into the RNA-based mechanism of action of the anticancer drug 5'-fluorouracil in eukaryotic cells. PLoS ONE 2013, 8, e78172. [CrossRef] [PubMed]

23. Pritchard, D.M.; Watson, A.J.; Potten, C.S.; Jackman, A.L.; Hickman, J.A. Inhibition by uridine but not thymidine of p53-dependent intestinal apoptosis initiated by 5-fluorouracil: Evidence for the involvement of RNA perturbation. Proc. Natl. Acad. Sci. USA 1997, 94, 1795-1799. [CrossRef]

24. Sun, X.X.; Dai, M.S.; Lu, H. 5-fluorouracil activation of p53 involves an MDM2-ribosomal protein interaction. J. Biol. Chem. 2007, 282, 8052-8059. [CrossRef] [PubMed]

25. Van Groeningen, C.J.; Peters, G.J.; Leyva, A.; Laurensse, E.; Pinedo, H.M. Reversal of 5-fluorouracil-induced myelosuppression by prolonged administration of high-dose uridine. J. Natl. Cancer Inst. 1989, 81, 157-162. [CrossRef]

26. Soares, P.M.; Mota, J.M.; Souza, E.P.; Justino, P.F.; Franco, A.X.; Cunha, F.Q.; Ribeiro, R.A.; Souza, M.H. Inflammatory intestinal damage induced by 5-fluorouracil requires IL-4. Cytokine 2013, 61, 46-49. [CrossRef]

27. Gmeiner, W.H.; Debinski, W.; Milligan, C.; Caudell, D.; Pardee, T.S. The applications of the novel polymeric fluoropyrimidine F10 in cancer treatment: Current evidence. Future Oncol. 2016, 12, 2009-2020. [CrossRef]

28. Gmeiner, W.H.; Miller, L.D.; Chou, J.W.; Dominijanni, A.; Mutkus, L.; Marini, F.; Ruiz, J.; Dotson, T.; Thomas, K.W.; Parks, G.; et al. Dysregulated Pyrimidine Biosynthesis Contributes to 5-FU Resistance in SCLC Patient-Derived Organoids but Response to a Novel Polymeric Fluoropyrimidine, CF10. Cancers 2020, 12, 788. [CrossRef]

29. Arnold, M.; Sierra, M.S.; Laversanne, M.; Soerjomataram, I.; Jemal, A.; Bray, F. Global patterns and trends in colorectal cancer incidence and mortality. Gut 2017, 66, 683-691. [CrossRef] 
30. Bastos, D.A.; Ribeiro, S.C.; de Freitas, D.; Hoff, P.M. Combination therapy in high-risk stage II or stage III colon cancer: Current practice and future prospects. Ther. Adv. Med. Oncol. 2010, 2, 261-272. [CrossRef]

31. Wolmark, N.; Fisher, B.; Rockette, H.; Redmond, C.; Wickerham, D.L.; Fisher, E.R.; Jones, J.; Glass, A.; Lerner, H.; Lawrence, W.; et al. Postoperative adjuvant chemotherapy or BCG for colon cancer: Results from NSABP protocol C-01. J. Natl. Cancer Inst. 1988, 80, 30-36. [CrossRef] [PubMed]

32. Shikina, A.; Shinto, E.; Hashiguchi, Y.; Ueno, H.; Naito, Y.; Okamoto, K.; Kubo, T.; Fukazawa, S.; Yamamoto, J.; Hase, K. Differential clinical benefits of 5-fluorouracil-based adjuvant chemotherapy for patients with stage III colorectal cancer according to CD133 expression status. Jpn. J. Clin. Oncol. 2014, 44, 42-48. [CrossRef] [PubMed]

33. Tsai, Y.J.; Lin, J.K.; Chen, W.S.; Jiang, J.K.; Teng, H.W.; Yen, C.C.; Lin, T.C.; Yang, S.H. Adjuvant FOLFOX treatment for stage III colon cancer: How many cycles are enough? Springerplus 2016, 5, 1318. [CrossRef] [PubMed]

34. Mohelnikova-Duchonova, B.; Melichar, B.; Soucek, P. FOLFOX/FOLFIRI pharmacogenetics: The call for a personalized approach in colorectal cancer therapy. World J. Gastroenterol. 2014, 20, 10316-10330. [CrossRef] [PubMed]

35. Galluzzi, L.; Buque, A.; Kepp, O.; Zitvogel, L.; Kroemer, G. Immunological Effects of Conventional Chemotherapy and Targeted Anticancer Agents. Cancer Cell 2015, 28, 690-714. [CrossRef]

36. Fang, H.; Ang, B.; Xu, X.; Huang, X.; Wu, Y.; Sun, Y.; Wang, W.; Li, N.; Cao, X.; Wan, T. TLR4 is essential for dendritic cell activation and anti-tumor T-cell response enhancement by DAMPs released from chemically stressed cancer cells. Cell. Mol. Immunol. 2014, 11, 150-159. [CrossRef]

37. Vincent, J.; Mignot, G.; Chalmin, F.; Ladoire, S.; Bruchard, M.; Chevriaux, A.; Martin, F.; Apetoh, L.; Rebe, C.; Ghiringhelli, F. 5-Fluorouracil selectively kills tumor-associated myeloid-derived suppressor cells resulting in enhanced T cell-dependent antitumor immunity. Cancer Res. 2010, 70, 3052-3061. [CrossRef]

38. Vincent, J.; Mignot, G.; Chalmin, F.; Chang, C.T.; Ho, T.Y.; Lin, H.; Liang, J.A.; Huang, H.C.; Li, C.C.; Lo, H.Y.; et al. 5-Fluorouracil induced intestinal mucositis via nuclear factor-kappaB activation by transcriptomic analysis and in vivo bioluminescence imaging. PLoS ONE 2012, 7, e31808. [CrossRef]

39. Li, X.; Slayton, W.B. Molecular mechanisms of platelet and stem cell rebound after 5-fluorouracil treatment. Exp. Hematol. 2013, 41, 635-645 e63. [CrossRef]

40. Garg, M.B.; Lincz, L.F.; Adler, K.; Scorgie, F.E.; Ackland, S.P.; Sakoff, J.A. Predicting 5-fluorouracil toxicity in colorectal cancer patients from peripheral blood cell telomere length: A multivariate analysis. Br. J. Cancer 2012, 107, 1525-1533. [CrossRef]

41. Yamamoto, S.; Kawasaki, T. Active transport of 5-fluorouracil and its energy coupling in Ehrlich ascites tumor cells. J. Biochem. 1981, 90, 635-642. [CrossRef] [PubMed]

42. Weckbecker, G. Biochemical pharmacology and analysis of fluoropyrimidines alone and in combination with modulators. Pharm. Ther. 1991, 50,367-424. [CrossRef]

43. Saif, M.W.; Syrigos, K.; Mehra, R.; Mattison, L.K.; Diasio, R.B. Dihydropyrimidine Dehydrogenase Deficiency (DPD) in Gi Malignancies: Experience of 4-Years. Pak. J. Med. Sci. 2007, 23, 832-839.

44. Lee, A.M.; Shi, Q.; Pavey, E.; Alberts, S.R.; Sargent, D.J.; Sinicrope, F.A.; Berenberg, J.L.; Goldberg, R.M.; Diasio, R.B. DPYD variants as predictors of 5-fluorouracil toxicity in adjuvant colon cancer treatment (NCCTG N0147). J. Natl. Cancer Inst. 2014, 106. [CrossRef]

45. El-Rayes, B. Managing Severe Toxicities Associated with 5-FU and Capecitabine: An Oncologists's Perspective. Medscape Educ. Oncol. 2017. Available online: https://www.medscape.org/viewarticle/872909_sidebar2 (accessed on 15 May 2020).

46. Lee, J.J.; Beumer, J.H.; Chu, E. Therapeutic drug monitoring of 5-fluorouracil. Cancer Chemother. Pharm. 2016, 78, 447-464. [CrossRef]

47. Noordhuis, P.; Holwerda, U.; Van der Wilt, C.L.; Van Groeningen, C.J.; Smid, K.; Meijer, S.; Pinedo, H.M.; Peters, G.J. 5-Fluorouracil incorporation into RNA and DNA in relation to thymidylate synthase inhibition of human colorectal cancers. Ann. Oncol. 2004, 15, 1025-1032. [CrossRef]

48. Saif, M.W.; Diasio, R.B. Benefit of uridine triacetate (Vistogard) in rescuing severe 5-fluorouracil toxicity in patients with dihydropyrimidine dehydrogenase (DPYD) deficiency. Cancer Chemother. Pharm. 2016, 78, 151-156. [CrossRef] 
49. Houghton, J.A.; Tillman, D.M.; Harwood, F.G. Ratio of 2'-deoxyadenosine-5'-triphosphate/thymidine-5'triphosphate influences the commitment of human colon carcinoma cells to thymineless death. Clin. Cancer Res. 1995, 1, 723-730.

50. Mani, C.; Pai, S.; Papke, C.M.; Palle, K.; Gmeiner, W.H. Thymineless Death by the Fluoropyrimidine Polymer F10 Involves Replication Fork Collapse and Is Enhanced by Chk1 Inhibition. Neoplasia 2018, 20, 1236-1245. [CrossRef]

51. Liao, Z.Y.; Sordet, O.; Zhang, H.L.; Kohlhagen, G.; Antony, S.; Gmeiner, W.H.; Pommier, Y. A novel polypyrimidine antitumor agent FdUMP[10] induces thymineless death with topoisomerase I-DNA complexes. Cancer Res. 2005, 65, 4844-4851. [CrossRef] [PubMed]

52. Gmeiner, W.H.; Reinhold, W.C.; Pommier, Y. Genome-wide mRNA and microRNA profiling of the NCI 60 cell-line screen and comparison of FdUMP[10] with fluorouracil, floxuridine, and topoisomerase 1 poisons. Mol. Cancer Ther. 2010, 9, 3105-3114. [CrossRef] [PubMed]

53. Houghton, J.A.; Harwood, F.G.; Tillman, D.M. Thymineless death in colon carcinoma cells is mediated via fas signaling. Proc. Natl. Acad. Sci. USA 1997, 94, 8144-8149. [CrossRef] [PubMed]

54. Houghton, J.A.; Harwood, F.G.; Gibson, A.A.; Tillman, D.M. The fas signaling pathway is functional in colon carcinoma cells and induces apoptosis. Clin. Cancer Res. 1997, 3, 2205-2209.

55. Gmeiner, W.H.; Jennings-Gee, J.; Stuart, C.H.; Pardee, T.S. Thymineless death in F10-treated AML cells occurs via lipid raft depletion and Fas/FasL co-localization in the plasma membrane with activation of the extrinsic apoptotic pathway. Leuk. Res. 2015, 39, 229-235. [CrossRef]

56. Hassin, D.; Garber, O.G.; Meiraz, A.; Schiffenbauer, Y.S.; Berke, G. Cytotoxic T lymphocyte perforin and Fas ligand working in concert even when Fas ligand lytic action is still not detectable. Immunology 2011, 133, 190-196. [CrossRef]

57. Sahasrabudhe, P.V.; Pon, R.T.; Gmeiner, W.H. Solution structures of 5-fluorouracil-substituted DNA and RNA decamer duplexes. Biochemistry 1996, 35, 13597-13608. [CrossRef]

58. Sahasrabudhe, P.V.; Sun, J.; Gmeiner, W.H. The 5' stem-loop from human U4 snRNA adopts a novel conformation stabilized by G-C and G-U base pairs. J. Biomol. Struct. Dyn. 1997, 14, 567-577. [CrossRef]

59. Sahasrabudhe, P.V.; Gmeiner, W.H. Solution structures of 5-fluorouracil-substituted RNA duplexes containing G-U wobble base pairs. Biochemistry 1997, 36, 5981-5991. [CrossRef]

60. Sahasrabudhe, P.V.; Pon, R.T.; Gmeiner, W.H. Effects of site-specific substitution of 5-fluorouridine on the stabilities of duplex DNA and RNA. Nucleic. Acids Res. 1995, 23, 3916-3921. [CrossRef]

61. Warny, M.; Helby, J.; Nordestgaard, B.G.; Birgens, H.; Bojesen, S.E. Lymphopenia and risk of infection and infection-related death in 98,344 individuals from a prospective Danish population-based study. PLoS Med. 2018, 15, e1002685. [CrossRef] [PubMed]

62. Cao, S.; Baccanari, D.P.; Rustum, Y.M.; Davis, S.T.; Tansik, R.L.; Porter, D.J.; Spector, T. Alpha-fluoro-beta-alanine: Effects on the antitumor activity and toxicity of 5-fluorouracil. Biochem. Pharm. 2000, 59, 953-960. [CrossRef]

63. Sara, J.D.; Kaur, J.; Khodadadi, R.; Rehman, M.; Lobo, R.; Chakrabarti, S.; Herrmann, J.; Lerman, A.; Grothey, A. 5-fluorouracil and cardiotoxicity: A review. Ther. Adv. Med. Oncol. 2018, 10. [CrossRef]

64. Guo, X.D.; Harold, N.; Saif, M.W.; Schuler, B.; Szabo, E.; Hamilton, J.M.; Monahan, B.P.; Quinn, M.G.; Cliatt, J.; Nguyen, D.; et al. Pharmacokinetic and pharmacodynamic effects of oral eniluracil, fluorouracil and leucovorin given on a weekly schedule. Cancer Chemother. Pharm. 2003, 52, 79-85. [CrossRef]

65. Yamashita, K.; Yada, H.; Ariyoshi, T. Neurotoxic effects of alpha-fluoro-beta-alanine (FBAL) and fluoroacetic acid (FA) on dogs. J. Toxicol. Sci 2004, 29, 155-166. [CrossRef]

66. Nishikawa, Y.; Funakoshi, T.; Horimatsu, T.; Miyamoto, S.; Matsubara, T.; Yanagita, M.; Nakagawa, S.; Yonezawa, A.; Matsubara, K.; Muto, M. Accumulation of alpha-fluoro-beta-alanine and fluoro mono acetate in a patient with 5-fluorouracil-associated hyperammonemia. Cancer Chemother. Pharm. 2017, 79, 629-633. [CrossRef] [PubMed]

67. Sukumar, M.; Kishton, R.J.; Restifo, N.P. Metabolic reprograming of anti-tumor immunity. Curr. Opin. Immunol. 2017, 46, 14-22. [CrossRef]

68. Bracci, L.; Schiavoni, G.; Sistigu, A.; Belardelli, F. Immune-based mechanisms of cytotoxic chemotherapy: Implications for the design of novel and rationale-based combined treatments against cancer. Cell Death Differ. 2014, 21, 15-25. [CrossRef] 
69. Proietti, E.; Moschella, F.; Capone, I.; Belardelli, F. Exploitation of the propulsive force of chemotherapy for improving the response to cancer immunotherapy. Mol. Oncol. 2012, 6, 1-14. [CrossRef]

70. Ito, S.E.; Shirota, H.; Kasahara, Y.; Saijo, K.; Ishioka, C. IL-4 blockade alters the tumor microenvironment and augments the response to cancer immunotherapy in a mouse model. Cancer Immunol. Immunother. 2017, 66, 1485-1496. [CrossRef]

71. Li, H.L.; Lu, L.; Wang, X.S.; Qin, L.Y.; Wang, P.; Qiu, S.P.; Wu, H.; Huang, F.; Zhang, B.B.; Shi, H.L.; et al. Alteration of Gut Microbiota and Inflammatory Cytokine/Chemokine Profiles in 5-Fluorouracil Induced Intestinal Mucositis. Front. Cell. Infect. Microbiol. 2017, 7, 455. [CrossRef] [PubMed]

72. Alizadeh, D.; Larmonier, N. Chemotherapeutic targeting of cancer-induced immunosuppressive cells. Cancer Res. 2014, 74, 2663-2668. [CrossRef] [PubMed]

73. Gabrilovich, D.I. Myeloid-Derived Suppressor Cells. Cancer Immunol. Res. 2017, 5, 3-8. [CrossRef] [PubMed]

74. Wang, Z.; Till, B.; Gao, Q. Chemotherapeutic agent-mediated elimination of myeloid-derived suppressor cells. Oncoimmunology 2017, 6, e1331807. [CrossRef] [PubMed]

75. Corthay, A. How do regulatory T cells work? Scand. J. Immunol. 2009, 70, 326-336. [CrossRef]

76. Ohta, A.; Sitkovsky, M. Extracellular adenosine-mediated modulation of regulatory T cells. Front. Immunol. 2014, 5, 304. [CrossRef]

77. Vigano, S.; Alatzoglou, D.; Irving, M.; Menetrier-Caux, C.; Caux, C.; Romero, P.; Coukos, G. Targeting Adenosine in Cancer Immunotherapy to Enhance T-Cell Function. Front. Immunol 2019, 10, 925. [CrossRef]

78. Ohue, Y.; Nishikawa, H. Regulatory T (Treg) cells in cancer: Can Treg cells be a new therapeutic target? Cancer Sci. 2019, 110, 2080-2089. [CrossRef]

79. Zhang, X.; Kelaria, S.; Kerstetter, J.; Wang, J. The functional and prognostic implications of regulatory T cells in colorectal carcinoma. J. Gastrointest. Oncol. 2015, 6, 307-313. [CrossRef]

80. Walker, L.S. Treg and CTLA-4: Two intertwining pathways to immune tolerance. J. Autoimmun. 2013, 45, 49-57. [CrossRef]

81. OuYang, L.Y.; Wu, X.J.; Ye, S.B.; Zhang, R.X.; Li, Z.L.; Liao, W.; Pan, Z.Z.; Zheng, L.M.; Zhang, X.S.; Wang, Z.; et al. Tumor-induced myeloid-derived suppressor cells promote tumor progression through oxidative metabolism in human colorectal cancer. J. Transl. Med. 2015, 13, 47. [CrossRef] [PubMed]

82. Yang, R.; Cai, T.T.; Wu, X.J.; Liu, Y.N.; He, J.; Zhang, X.S.; Ma, G.; Li, J. Tumour YAP1 and PTEN expression correlates with tumour-associated myeloid suppressor cell expansion and reduced survival in colorectal cancer. Immunology 2018, 155, 263-272. [CrossRef]

83. Wang, Q.; Feng, M.; Yu, T.; Liu, X.; Zhang, P. Intratumoral regulatory T cells are associated with suppression of colorectal carcinoma metastasis after resection through overcoming IL-17 producing T cells. Cell. Immunol. 2014, 287, 100-105. [CrossRef] [PubMed]

84. Zhuo, C.; Xu, Y.; Ying, M.; Li, Q.; Huang, L.; Li, D.; Cai, S.; Li, B. FOXP3+ Tregs: Heterogeneous phenotypes and conflicting impacts on survival outcomes in patients with colorectal cancer. Immunol. Res. 2015, 61, 338-347. [CrossRef] [PubMed]

85. Le, H.K.; Graham, L.; Cha, E.; Morales, J.K.; Manjili, M.H.; Bear, H.D. Gemcitabine directly inhibits myeloid derived suppressor cells in BALB/c mice bearing 4T1 mammary carcinoma and augments expansion of T cells from tumor-bearing mice. Int. Immunopharmacol. 2009, 9, 900-909. [CrossRef]

86. Orecchioni, S.; Talarico, G.; Labanca, V.; Calleri, A.; Mancuso, P.; Bertolini, F. Vinorelbine, cyclophosphamide and 5-FU effects on the circulating and intratumoural landscape of immune cells improve anti-PD-L1 efficacy in preclinical models of breast cancer and lymphoma. Br. J. Cancer 2018, 118, 1329-1336. [CrossRef]

87. Limagne, E.; Euvrard, R.; Thibaudin, M.; Rebe, C.; Derangere, V.; Chevriaux, A.; Boidot, R.; Vegran, F.; Bonnefoy, N.; Vincent, J.; et al. Accumulation of MDSC and Th17 Cells in Patients with Metastatic Colorectal Cancer Predicts the Efficacy of a FOLFOX-Bevacizumab Drug Treatment Regimen. Cancer Res. 2016, 76, 5241-5252. [CrossRef] [PubMed]

88. Kanterman, J.; Sade-Feldman, M.; Biton, M.; Ish-Shalom, E.; Lasry, A.; Goldshtein, A.; Hubert, A.; Baniyash, M. Adverse immunoregulatory effects of 5FU and CPT11 chemotherapy on myeloid-derived suppressor cells and colorectal cancer outcomes. Cancer Res. 2014, 74, 6022-6035. [CrossRef] [PubMed]

89. Roselli, M.; Formica, V.; Cereda, V.; Jochems, C.; Richards, J.; Grenga, I.; Orlandi, A.; Ferroni, P.; Guadagni, F.; Schlom, J. The association of clinical outcome and peripheral T-cell subsets in metastatic colorectal cancer patients receiving first-line FOLFIRI plus bevacizumab therapy. Oncoimmunology 2016, 5, e1188243. [CrossRef] 
90. Galon, J.; Mlecnik, B.; Bindea, G.; Angell, H.K.; Berger, A.; Lagorce, C.; Lugli, A.; Zlobec, I.; Hartmann, A.; Bifulco, C.; et al. Towards the introduction of the 'Immunoscore' in the classification of malignant tumours. J. Pathol. 2014, 232, 199-209. [CrossRef]

91. Pages, F.; Mlecnik, B.; Marliot, F.; Bindea, G.; Ou, F.S.; Bifulco, C.; Lugli, A.; Zlobec, I.; Rau, T.T.; Berger, M.D.; et al. International validation of the consensus Immunoscore for the classification of colon cancer: A prognostic and accuracy study. Lancet 2018, 391, 2128-2139. [CrossRef]

92. Krijgsman, D.; de Vries, N.L.; Skovbo, A.; Andersen, M.N.; Swets, M.; Bastiaannet, E.; Vahrmeijer, A.L.; van de Velde, C.J.H.; Heemskerk, M.H.M.; Hokland, M.; et al. Characterization of circulating T-, NK-, and NKT cell subsets in patients with colorectal cancer: The peripheral blood immune cell profile. Cancer Immunol. Immunother. 2019, 68, 1011-1024. [CrossRef] [PubMed]

93. Rocca, Y.S.; Roberti, M.P.; Arriaga, J.M.; Amat, M.; Bruno, L.; Pampena, M.B.; Huertas, E.; Loria, F.S.; Pairola, A.; Bianchini, M.; et al. Altered phenotype in peripheral blood and tumor-associated NK cells from colorectal cancer patients. Innate Immun. 2013, 19, 76-85. [CrossRef] [PubMed]

94. Tang, Y.P.; Xie, M.Z.; Li, K.Z.; Li, J.L.; Cai, Z.M.; Hu, B.L. Prognostic value of peripheral blood natural killer cells in colorectal cancer. BMC Gastroenterol. 2020, 20,31. [CrossRef] [PubMed]

95. Jacobi, C.; Claus, M.; Wildemann, B.; Wingert, S.; Korporal, M.; Romisch, J.; Meuer, S.; Watzl, C.; Giese, T. Exposure of NK cells to intravenous immunoglobulin induces IFN gamma release and degranulation but inhibits their cytotoxic activity. Clin. Immunol. 2009, 133, 393-401. [CrossRef]

96. Cui, F.; Qu, D.; Sun, R.; Nan, K. Circulating CD16+CD56+ nature killer cells indicate the prognosis of colorectal cancer after initial chemotherapy. Med. Oncol. 2019, 36, 84. [CrossRef]

97. Shinko, D.; McGuire, H.M.; Diakos, C.I.; Pavlakis, N.; Clarke, S.J.; Byrne, S.N.; Charles, K.A. Mass Cytometry Reveals a Sustained Reduction in CD16+ Natural Killer Cells Following Chemotherapy in Colorectal Cancer Patients. Front. Immunol. 2019, 10, 2584. [CrossRef]

98. Galluzzi, L.; Buque, A.; Kepp, O.; Zitvogel, L.; Kroemer, G. Immunogenic cell death in cancer and infectious disease. Nat. Rev. Immunol. 2017, 17, 97-111. [CrossRef]

99. Panaretakis, T.; Joza, N.; Modjtahedi, N.; Tesniere, A.; Vitale, I.; Durchschlag, M.; Fimia, G.M.; Kepp, O.; Piacentini, M.; Froehlich, K.U.; et al. The co-translocation of ERp57 and calreticulin determines the immunogenicity of cell death. Cell Death Differ. 2008, 15, 1499-1509. [CrossRef]

100. Zhou, Y.J.; Binder, R.J. The heat shock protein-CD91 pathway mediates tumor immunosurveillance. Oncoimmunology 2014, 3, e28222. [CrossRef]

101. Wang, Y.; Martins, I.; Ma, Y.; Kepp, O.; Galluzzi, L.; Kroemer, G. Autophagy-dependent ATP release from dying cells via lysosomal exocytosis. Autophagy 2013, 9, 1624-1625. [CrossRef] [PubMed]

102. Apetoh, L.; Ghiringhelli, F.; Tesniere, A.; Criollo, A.; Ortiz, C.; Lidereau, R.; Mariette, C.; Chaput, N.; Mira, J.P.; Delaloge, S.; et al. The interaction between HMGB1 and TLR4 dictates the outcome of anticancer chemotherapy and radiotherapy. Immunol. Rev. 2007, 220, 47-59. [CrossRef] [PubMed]

103. Huang, F.Y.; Lei, J.; Sun, Y.; Yan, F.; Chen, B.; Zhang, L.; Lu, Z.; Cao, R.; Lin, Y.Y.; Wang, C.C.; et al. Induction of enhanced immunogenic cell death through ultrasound-controlled release of doxorubicin by liposome-microbubble complexes. Oncoimmunology 2018, 7, e1446720. [CrossRef] [PubMed]

104. Castle, J.C.; Loewer, M.; Boegel, S.; de Graaf, J.; Bender, C.; Tadmor, A.D.; Boisguerin, V.; Bukur, T.; Sorn, P.; Paret, C.; et al. Immunomic, genomic and transcriptomic characterization of CT26 colorectal carcinoma. BMC Genom. 2014, 15, 190. [CrossRef] [PubMed]

105. Iacopetta, B. TP53 mutation in colorectal cancer. Hum. Mutat. 2003, 21, 271-276. [CrossRef]

106. Bunz, F.; Hwang, P.M.; Torrance, C.; Waldman, T.; Zhang, Y.; Dillehay, L.; Williams, J.; Lengauer, C.; Kinzler, K.W.; Vogelstein, B. Disruption of p53 in human cancer cells alters the responses to therapeutic agents. J. Clin. Investig. 1999, 104, 263-269. [CrossRef]

107. Kandioler, D.; Mittlbock, M.; Kappel, S.; Puhalla, H.; Herbst, F.; Langner, C.; Wolf, B.; Tschmelitsch, J.; Schippinger, W.; Steger, G.; et al. TP53 Mutational Status and Prediction of Benefit from Adjuvant 5-Fluorouracil in Stage III Colon Cancer Patients. EBioMedicine 2015, 2, 825-830. [CrossRef]

108. Pardee, T.S.; Gomes, E.; Jennings-Gee, J.; Caudell, D.; Gmeiner, W.H. Unique dual targeting of thymidylate synthase and topoisomerase1 by FdUMP[10] results in high efficacy against AML and low toxicity. Blood 2012, 119, 3561-3570. [CrossRef] [PubMed] 
109. Arshad, U.; Ploylearmsaeng, S.A.; Karlsson, M.O.; Doroshyenko, O.; Langer, D.; Schomig, E.; Kunze, S.; Guner, S.A.; Skripnichenko, R.; Ullah, S.; et al. Prediction of exposure-driven myelotoxicity of continuous infusion 5-fluorouracil by a semi-physiological pharmacokinetic-pharmacodynamic model in gastrointestinal cancer patients. Cancer Chemother. Pharm. 2020, 85, 711-722. [CrossRef] [PubMed]

110. Delea, T.E.; Vera-Llonch, M.; Edelsberg, J.S.; McGarry, L.; Anton, S.; Ulcickas-Yood, M.; Oster, G. The incidence and cost of hospitalization for 5-FU toxicity among Medicare beneficiaries with metastatic colorectal cancer. Value Health 2002, 5, 35-43. [CrossRef] [PubMed]

111. Randall, T.D.; Weissman, I.L. Phenotypic and functional changes induced at the clonal level in hematopoietic stem cells after 5-fluorouracil treatment. Blood 1997, 89, 3596-3606. [CrossRef] [PubMed]

112. Wu, Y.; Deng, Z.; Wang, H.; Ma, W.; Zhou, C.; Zhang, S. Repeated cycles of 5-fluorouracil chemotherapy impaired anti-tumor functions of cytotoxic T cells in a CT26 tumor-bearing mouse model. BMC Immunol. 2016, 17, 29. [CrossRef] [PubMed]

113. Von Hoff, D.D. In vitro data supporting interferon plus cytotoxic agent combinations. Semin. Oncol. 1991, 18, 58-61. [PubMed]

114. Schwartz, E.L.; Hoffman, M.; O'Connor, C.J.; Wadler, S. Stimulation of 5-fluorouracil metabolic activation by interferon-alpha in human colon carcinoma cells. Biochem. Biophys. Res. Commun. 1992, 182, 1232-1239. [CrossRef]

115. Van der Wilt, C.L.; Smid, K.; Aherne, G.W.; Noordhuis, P.; Peters, G.J. Biochemical mechanisms of interferon modulation of 5-fluorouracil activity in colon cancer cells. Eur. J. Cancer 1997, 33, 471-478. [CrossRef]

116. Grem, J.L.; McAtee, N.; Murphy, R.F.; Balis, F.M.; Steinberg, S.M.; Hamilton, J.M.; Sorensen, J.M.; Sartor, O.; Kramer, B.S.; Goldstein, L.J.; et al. A pilot study of interferon alfa-2a in combination with fluorouracil plus high-dose leucovorin in metastatic gastrointestinal carcinoma. J. Clin. Oncol. 1991, 9, 1811-1820. [CrossRef]

117. Yee, L.K.; Allegra, C.J.; Steinberg, S.M.; Grem, J.L. Decreased catabolism of fluorouracil in peripheral blood mononuclear cells during combination therapy with fluorouracil, leucovorin, and interferon alpha-2a. J. Natl. Cancer Inst. 1992, 84, 1820-1825. [CrossRef]

118. Raderer, M.; Scheithauer, W. Treatment of advanced colorectal cancer with 5-fluorouracil and interferon-alpha: An overview of clinical trials. Eur. J. Cancer 1995, 31A, 1002-1008. [CrossRef]

119. Castro, F.; Cardoso, A.P.; Goncalves, R.M.; Serre, K.; Oliveira, M.J. Interferon-Gamma at the Crossroads of Tumor Immune Surveillance or Evasion. Front. Immunol. 2018, 9, 847. [CrossRef]

120. Aquino, A.; Prete, S.P.; Greiner, J.W.; Giuliani, A.; Graziani, G.; Turriziani, M.; De Filippi, R.; Masci, G.; Bonmassar, E.; De Vecchis, L. Effect of the combined treatment with 5-fluorouracil, gamma-interferon or folinic acid on carcinoembryonic antigen expression in colon cancer cells. Clin. Cancer Res. 1998, 4, 2473-2481.

121. Wiesenfeld, M.; O'Connell, M.J.; Wieand, H.S.; Gonchoroff, N.J.; Donohue, J.H.; Fitzgibbons, R.J., Jr.; Krook, J.E.; Mailliard, J.A.; Gerstner, J.B.; Pazdur, R. Controlled clinical trial of interferon-gamma as postoperative surgical adjuvant therapy for colon cancer. J. Clin. Oncol 1995, 13, 2324-2329. [CrossRef] [PubMed]

122. Kim, J.S.; Park, Y.M.; Kim, N.Y.; Yun, H.K.; Lee, K.J.; Kim, B.H.; Park, S.J.; Yeon, J.W.; Jung, G. Combination treatment with intrahepatic arterial infusion and intratumoral injection chemotherapy in patients with far-advanced hepatocellular carcinoma and arterioportal or arteriovenous shunts: Preliminary results. Korean J. Hepatol. 2011, 17, 120-129. [CrossRef] [PubMed]

123. Burnette, B.C.; Liang, H.; Lee, Y.; Chlewicki, L.; Khodarev, N.N.; Weichselbaum, R.R.; Fu, Y.X.; Auh, S.L. The efficacy of radiotherapy relies upon induction of type i interferon-dependent innate and adaptive immunity. Cancer Res. 2011, 71, 2488-2496. [CrossRef] [PubMed]

124. Deng, L.; Liang, H.; Xu, M.; Yang, X.; Burnette, B.; Arina, A.; Li, X.D.; Mauceri, H.; Beckett, M.; Darga, T.; et al. STING-Dependent Cytosolic DNA Sensing Promotes Radiation-Induced Type I Interferon-Dependent Antitumor Immunity in Immunogenic Tumors. Immunity 2014, 41, 843-852. [CrossRef] [PubMed]

125. Ho, S.S.; Zhang, W.Y.; Tan, N.Y.; Khatoo, M.; Suter, M.A.; Tripathi, S.; Cheung, F.S.; Lim, W.K.; Tan, P.H.; Ngeow, J.; et al. The DNA Structure-Specific Endonuclease MUS81 Mediates DNA Sensor STING-Dependent Host Rejection of Prostate Cancer Cells. Immunity 2016, 44, 1177-1189. [CrossRef] [PubMed]

126. Regairaz, M.; Zhang, Y.W.; Fu, H.; Agama, K.K.; Tata, N.; Agrawal, S.; Aladjem, M.I.; Pommier, Y. Mus81-mediated DNA cleavage resolves replication forks stalled by topoisomerase I-DNA complexes. J. Cell Biol. 2011, 195, 739-749. [CrossRef] 
127. Li, T.; Cheng, H.; Yuan, H.; Xu, Q.; Shu, C.; Zhang, Y.; Xu, P.; Tan, J.; Rui, Y.; Li, P.; et al. Antitumor Activity of cGAMP via Stimulation of cGAS-cGAMP-STING-IRF3 Mediated Innate Immune Response. Sci. Rep. 2016, 6, 19049. [CrossRef]

128. Benmerzoug, S.; Rose, S.; Bounab, B.; Gosset, D.; Duneau, L.; Chenuet, P.; Mollet, L.; Le Bert, M.; Lambers, C.; Geleff, S.; et al. STING-dependent sensing of self-DNA drives silica-induced lung inflammation. Nat. Commun. 2018, 9, 5226. [CrossRef]

129. Woo, S.R.; Fuertes, M.B.; Corrales, L.; Spranger, S.; Furdyna, M.J.; Leung, M.Y.; Duggan, R.; Wang, Y.; Barber, G.N.; Fitzgerald, K.A.; et al. STING-dependent cytosolic DNA sensing mediates innate immune recognition of immunogenic tumors. Immunity 2014, 41, 830-842. [CrossRef]

130. Klarquist, J.; Hennies, C.M.; Lehn, M.A.; Reboulet, R.A.; Feau, S.; Janssen, E.M. STING-mediated DNA sensing promotes antitumor and autoimmune responses to dying cells. J. Immunol. 2014, 193, 6124-6134. [CrossRef]

131. Lemos, H.; Huang, L.; McGaha, T.L.; Mellor, A.L. Cytosolic DNA sensing via the stimulator of interferon genes adaptor: Yin and Yang of immune responses to DNA. Eur. J. Immunol. 2014, 44, 2847-2853. [CrossRef] [PubMed]

132. Lemos, H.; Mohamed, E.; Huang, L.; Ou, R.; Pacholczyk, G.; Arbab, A.S.; Munn, D.; Mellor, A.L. STING Promotes the Growth of Tumors Characterized by Low Antigenicity via IDO Activation. Cancer Res. 2016, 76, 2076-2081. [CrossRef] [PubMed]

133. Jain, P.; Jain, C.; Velcheti, V. Role of immune-checkpoint inhibitors in lung cancer. Ther. Adv. Respir. Dis. 2018, 12. [CrossRef] [PubMed]

134. Kawakami, H.; Zaanan, A.; Sinicrope, F.A. Microsatellite instability testing and its role in the management of colorectal cancer. Curr. Treat. Options Oncol. 2015, 16, 30. [CrossRef] [PubMed]

135. Kim, S.T.; Klempner, S.J.; Park, S.H.; Park, J.O.; Park, Y.S.; Lim, H.Y.; Kang, W.K.; Kim, K.M.; Lee, J. Correlating programmed death ligand 1 (PD-L1) expression, mismatch repair deficiency, and outcomes across tumor types: Implications for immunotherapy. Oncotarget 2017, 8, 77415-77423. [CrossRef] [PubMed]

136. Llosa, N.J.; Cruise, M.; Tam, A.; Wicks, E.C.; Hechenbleikner, E.M.; Taube, J.M.; Blosser, R.L.; Fan, H.; Wang, H.; Luber, B.S.; et al. The vigorous immune microenvironment of microsatellite instable colon cancer is balanced by multiple counter-inhibitory checkpoints. Cancer Discov. 2015, 5, 43-51. [CrossRef]

137. Fabrizio, D.A.; George, T.J., Jr.; Dunne, R.F.; Frampton, G.; Sun, J.; Gowen, K.; Kennedy, M.; Greenbowe, J.; Schrock, A.B.; Hezel, A.F.; et al. Beyond microsatellite testing: Assessment of tumor mutational burden identifies subsets of colorectal cancer who may respond to immune checkpoint inhibition. J. Gastrointest. Oncol. 2018, 9, 610-617. [CrossRef]

138. Van Der Kraak, L.; Goel, G.; Ramanan, K.; Kaltenmeier, C.; Zhang, L.; Normolle, D.P.; Freeman, G.J.; Tang, D.; Nason, K.S.; Davison, J.M.; et al. 5-Fluorouracil upregulates cell surface B7-H1 (PD-L1) expression in gastrointestinal cancers. J. Immunother. Cancer 2016, 4, 65. [CrossRef]

139. Bedi, D.; Henderson, H.J.; Manne, U.; Samuel, T. Camptothecin Induces PD-L1 and Immunomodulatory Cytokines in Colon Cancer Cells. Medicines 2019, 6, 51. [CrossRef]

140. Grasselly, C.; Denis, M.; Bourguignon, A.; Talhi, N.; Mathe, D.; Tourette, A.; Serre, L.; Jordheim, L.P.; Matera, E.L.; Dumontet, C. The Antitumor Activity of Combinations of Cytotoxic Chemotherapy and Immune Checkpoint Inhibitors Is Model-Dependent. Front. Immunol. 2018, 9, 2100. [CrossRef]

141. Dosset, M.; Vargas, T.R.; Lagrange, A.; Boidot, R.; Vegran, F.; Roussey, A.; Chalmin, F.; Dondaine, L.; Paul, C.; Lauret Marie-Joseph, E.; et al. PD-1/PD-L1 pathway: An adaptive immune resistance mechanism to immunogenic chemotherapy in colorectal cancer. Oncoimmunology 2018, 7, e1433981. [CrossRef] [PubMed]

142. Tintelnot, J.; Stein, A. Immunotherapy in colorectal cancer: Available clinical evidence, challenges and novel approaches. World J. Gastroenterol. 2019, 25, 3920-3928. [CrossRef] [PubMed]

143. Shahda, S.; Noonan, A.M.; Bekaii-Saab, T.S.; O’Neil, B.H.; Sehdev, A.; Shaib, W.L.; Helft, P.R.; Loehrer, P.J.; Tong, Y.; Liu, Z.; et al. A phase II study of pembrolizumab in combination with mFOLFOX6 for patients with advanced colorectal cancer. J. Clin. Oncol. 2017, 35 (Suppl. S15), 3541. [CrossRef]

144. Kim, R.; Chaves, J.; Kavan, P.; Fakih, M.; Kortmansky, J.; Spencer, K.; Wong, L.; Tehfe, M.; Li, J.J.; Lee, M.; et al. Pembrolizumab (pembro) plus mFOLFOX or FOLFIRI in patients with metastatic colorectal cancer (mCRC): KEYNOTE-651 cohorts B and D. Ann. Oncol. 2019, 30 (Suppl. S5), v229-v230. [CrossRef] 
145. Ensminger, W.D.; Rosowsky, A.; Raso, V.; Levin, D.C.; Glode, M.; Come, S.; Steele, G.; Frei, E., III. A clinical-pharmacological evaluation of hepatic arterial infusions of 5-fluoro-2'-deoxyuridine and 5-fluorouracil. Cancer Res. 1978; 38, 3784-3792.

146. Ensminger, W.D. Intrahepatic arterial infusion of chemotherapy: Pharmacologic principles. Semin. Oncol. 2002, 29, 119-125. [CrossRef] [PubMed]

147. Gmeiner, W.H.; Willingham, M.C.; Bourland, J.D.; Hatcher, H.C.; Smith, T.L.; D'Agostino, R.B., Jr.; Blackstock, W. F10 Inhibits Growth of PC3 Xenografts and Enhances the Effects of Radiation Therapy. J. Clin. Oncol. Res. 2014, 2, 1028.

148. Gmeiner, W.H.; Lema-Tome, C.; Gibo, D.; Jennings-Gee, J.; Milligan, C.; Debinski, W. Selective anti-tumor activity of the novel fluoropyrimidine polymer F10 towards G48a orthotopic GBM tumors. J. Neurooncol. 2014, 116, 447-454. [CrossRef]

149. Pardee, T.S.; Stadelman, K.; Jennings-Gee, J.; Caudell, D.L.; Gmeiner, W.H. The poison oligonucleotide F10 is highly effective against acute lymphoblastic leukemia while sparing normal hematopoietic cells. Oncotarget 2014, 5, 4170-4179. [CrossRef]

150. Dominijanni, A.; Gmeiner, W.H. Improved potency of F10 relative to 5-fluorouracil in colorectal cancer cells with p53 mutations. Cancer Drug Resist. 2018, 1, 48-58. [CrossRef]

(C) 2020 by the author. Licensee MDPI, Basel, Switzerland. This article is an open access article distributed under the terms and conditions of the Creative Commons Attribution (CC BY) license (http://creativecommons.org/licenses/by/4.0/). 